\title{
Pattern of extinction of the woolly mammoth in Beringia
}

\author{
G.M. MacDonald ${ }^{1}$, D.W. Beilman², Y.V. Kuzmin ${ }^{3}$, L.A. Orlova ${ }^{3}$, K.V. Kremenetski ${ }^{1}$, B. Shapiro ${ }^{4}$, \\ R.K. Wayne $e^{5} \&$ B. Van Valkenburgh ${ }^{5}$
}

Extinction of the woolly mammoth in Beringia has long been subject to research and speculation. Here we use a new geo-referenced database of radiocarbon-dated evidence to show that mammoths were abundant in the open-habitat of Marine Isotope Stage 3 ( 45-30 ka). During the Last Glacial Maximum ( $25-20 \mathrm{ka}$ ), northern populations declined while those in interior Siberia increased. Northern mammoths increased after the glacial maximum, but declined at and after the Younger Dryas ( 12.9-11.5 ka). Remaining continental mammoths, now concentrated in the north, disappeared in the early Holocene with development of extensive peatlands, wet tundra, birch shrubland and coniferous forest. Long sympatry in Siberia suggests that humans may be best seen as a synergistic cofactor in that extirpation. The extinction of island populations occurred at $\sim 4 \mathrm{ka}$. Mammoth extinction was not due to a single cause, but followed a long trajectory in concert with changes in climate, habitat and human presence.

\footnotetext{
1 UCLA, Departments of Geography and Ecology and Evolutionary Biology, UCLA, Los Angeles, California 90095-1524, USA; ${ }^{2}$ Department of Geography, University of Hawaii Manoa, 445 Saunders Hall, 2424 Maile Way, Honolulu, HI 96822, USA; ${ }^{3}$ Institute of Geology and Mineralogy, Siberian Branch of the Russian Academy of Sciences, Koptyug Ave. 3, Novosibirsk 630090, Russia; ${ }^{4}$ Department of Ecology and Evolutionary Biology, University of California Santa Cruz, 1156 High Street, Santa Cruz, CA 95064, USA; 5 Department of Ecology and Evolutionary Biology, UCLA, Los Angeles, CA 90095, USA. Correspondence and requests for materials should be addressed to G.M.M. (email: macdonal@geog.ucla.edu).
} 
W oolly mammoth (Mammuthus primigenius Blum.) were abundant in Beringia during the late Pleistocene before disappearing in the Holocene, and their extinction remains of wide interest and speculation ${ }^{1-13}$. The Pleistocene environment they occupied is often referred to as 'mammoth steppe', although the nature and chronology of this habitat has been debated ${ }^{5,9}$. Extinction has been attributed to one or a combination ${ }^{1,2,5,8}$ of factors including over-hunting by humans ${ }^{1,5,7,13}$, ecological displacement during the transition from the Last Glacial Maximum (LGM) to the warm and stable Holocene ${ }^{1,6-9}$, or impact by an extraterrestrial object ${ }^{14}$ at the time of the Younger Dryas (YD) climatic oscillation.

We reconstruct the detailed pattern of extinction in Beringia, the last redoubt of the mammoths, and examine these various extinction hypotheses by comparing spatially and temporally the changes in mammoth populations relative to environmental changes over the past $45 \mathrm{ka}(45,000 \mathrm{cal}$. years before present) using a georeferenced radiocarbon database of 1,323 woolly mammoth dates, 658 peatland initiation dates, 447 tree and wood macrofossil dates, 576 dates from Paleolithic archaeological sites ( $45 \mathrm{ka}-10 \mathrm{ka})$, palynological records and genetic data.

\section{Results}

Patterns of Mammoth Abundance during MIS 3. Of the 1,323 mammoth radiocarbon dates, 377 are infinite in age or classified as potentially $>45 \mathrm{ka}$. Finite-age mammoth remains are abundant from Marine Isotope Stage 3 (MIS 3), and notably common at northern sites, suggesting more favourable conditions for woolly mammoths in northernmost Asia and adjacent North America between 30 to $45 \mathrm{ka}$ than during the subsequent LGM (Figs 1-3). Mitochondrial DNA for Siberian woolly mammoths suggests that two distinct clades were extant during MIS 3 (ref. 15) (Supplementary Fig. S1). Paleolithic human sites in Asian Beringia and particularly its southern periphery are widely present during MIS 3 and demonstrate a long sympatry between humans and woolly mammoths in that region (Figs 1 and 2).

Maximum temperatures in Beringia during MIS 3 were slightly lower $\left(<2\right.$ to $\left.3^{\circ} \mathrm{C}\right)$ than during the Holocene $e^{16}$. June insolation was lower than the Holocene and December insolation was roughly equal (Fig. 1). Northerly areas supported a mosaic of open graminoid and herbaceous vegetation with shrubland. Conifers were present in interior areas ${ }^{17}$, although likely not as abundant as during the Holocene (Figs 1 and 4). A peak in the northern woolly mammoth populations during MIS 3 is consistent with the known ecology of the species and is supported by recent climate suitability modelling ${ }^{7}$. Mammoths were open vegetation-adapted with diets dominated by graminoids and soft-shoots of selected woody plants such as willow $(\text { Salix })^{4,9,18}$. Conifer trees, although found in the stomachs of some woolly mammoths, are not nutritious browse. Birch (Betula) can be toxic to cecal digesters, such as mammoths, which lack a rumen for detoxification ${ }^{5,9,18}$. While grasses and willows were plentiful, birch was less abundant during MIS 3 than its Late Glacial-Holocene maximum ${ }^{17}$ (Figs 1 and 4). Northern peatlands would have represented difficult terrain and a poor source of nutrition for mammoths. Relatively low abundances of Sphagnum moss spores in palynological records and a paucity of peat deposits from this period ${ }^{19}$ (Figs 1, 2 and 4) suggest that peatlands were less extensive than during the Holocene. In the north MIS 3, with relatively abundant grass and willow cover, may represent an environment closest to the idealized mammoth steppe.

Declines and shifts in mammoth abundance during the LGM. As summer insolation decreased during the LGM (MIS 2), woolly mammoth declined in both northernmost Asia and in northwestern North America (Figs 1-3). The decline in mammoth remains in northern Asia is statistically significant (3-group ANOVA test of mean number of dated samples per 5000 year time period for MIS 3 versus LGM versus Early Postglacial, $P<0.05)$. However, Asian populations overall remained large because of increases in central and southern Siberia. The increase in mammoth remains from the LGM compared with MIS 3 in southerly Siberia is statistically significant (ANOVA $P<0.05$ ).

Ancient mitochrondial $\mathrm{DNA}^{20}$ shows that the current genomics data do not offer the resolution required to detect any significant changes in effective population size during the transition from MIS 3 to the LGM (Supplementary Fig. S1). As seen previously ${ }^{21}$, the Bayesian skyline plot (BSP) of available data fails to recover any signature of mammoth decline or eventual extinction. We propose several explanations for this result. First, although the alignment comprises the mitochondrial hypervariable region, which should be the most rapidly evolving region of the mitochondrial genome, very few polymorphisms are observed in the mammoth sample. The data are therefore not sufficiently informative to estimate a mutation rate or to infer the demographic history of the mammoth population without resulting in wide confidence limits. Second, if extinction occurred rapidly, it would be nearly impossible to sample the individuals that would be representative of the few remaining populations. Third, the population structure will also influence the capacity to reconstruct the dynamics of an extinction. If the final few populations of mammoths were geographically isolated and genetically distinct, sampling one or a few individuals from each of these would result in no apparent loss of genetic diversity. In the current analysis, this fragmented landscape scenario may be indistinguishable from a large interbreeding population that remains constant in size. Finally, previous analyses that have used BSPs to infer Pleistocene demographic history used data sampled from populations that experienced a bottleneck and subsequent recovery ${ }^{22}$. Unfortunately, that recovery period may be necessary to capture the dynamics of the population decline. Although the specific timing is uncertain, mitochondrial DNA genologies do show that a northern chromosomal clade of woolly mammoth may have gone extinct during the LGM $^{15}$ (Supplementary Fig. S1).

Summers in Beringia during the LGM have been estimated to have been $6^{\circ} \mathrm{C}$ cooler than present and annual temperatures $4^{\circ} \mathrm{C}$ to $12^{\circ} \mathrm{C}$ below modern ${ }^{16,23}$. Although there was a mosaic of differing land covers, much of the environment was likely cold and dry with large areas of sparse vegetation ${ }^{5,16,23-25}$. Climatic suitability models predict a sharp decline in woolly mammoth habitat during the $\mathrm{LGM}^{7}$. The paleoecological data suggest that rather than a highly productive mammoth steppe of extensive lush grassland supporting large populations of grazers and browsers, at many northern locations, the LGM presented an 'extreme environment' with 'sparse forage' and is associated with mammoth population declines and possibly the loss of one genetic clade ${ }^{15}$ in the northern coastal area (Figs 1-4; Supplementary Fig. S1). The increase in mammoth remains and sites from more southerly portions of Siberia, particularly between $\sim 25$ and $20 \mathrm{ka}$, suggest a southward shift in the most favourable mammoth habitat during the LGM. Forest cover declined and this may have provided more open-habitat preferred by mammoths in interior regions (Figs 1-4). Mammoths also lived south of the the ice sheets in North America during the LGM, but consideration of the taxa there, environmental conditions, the presence or absence of human hunters, and the relative size of mammoth populations is beyond the scope of this paper.

Initial resurgence of northern mammoth populations following the LGM. As warming progressed following the LGM through the transition from MIS 2 to MIS 1, there was a strong resurgence of woolly mammoth in both northernmost Asia and Alaska/Yukon (Figs 1-3). The increase in mammoth remains in northern Asia and North America following the LGM is statistically significant (ANOVA $P<0.05$ ). Across northern Beringia, there were increasing temperatures and a likely increase in the productivity of herbaceous 

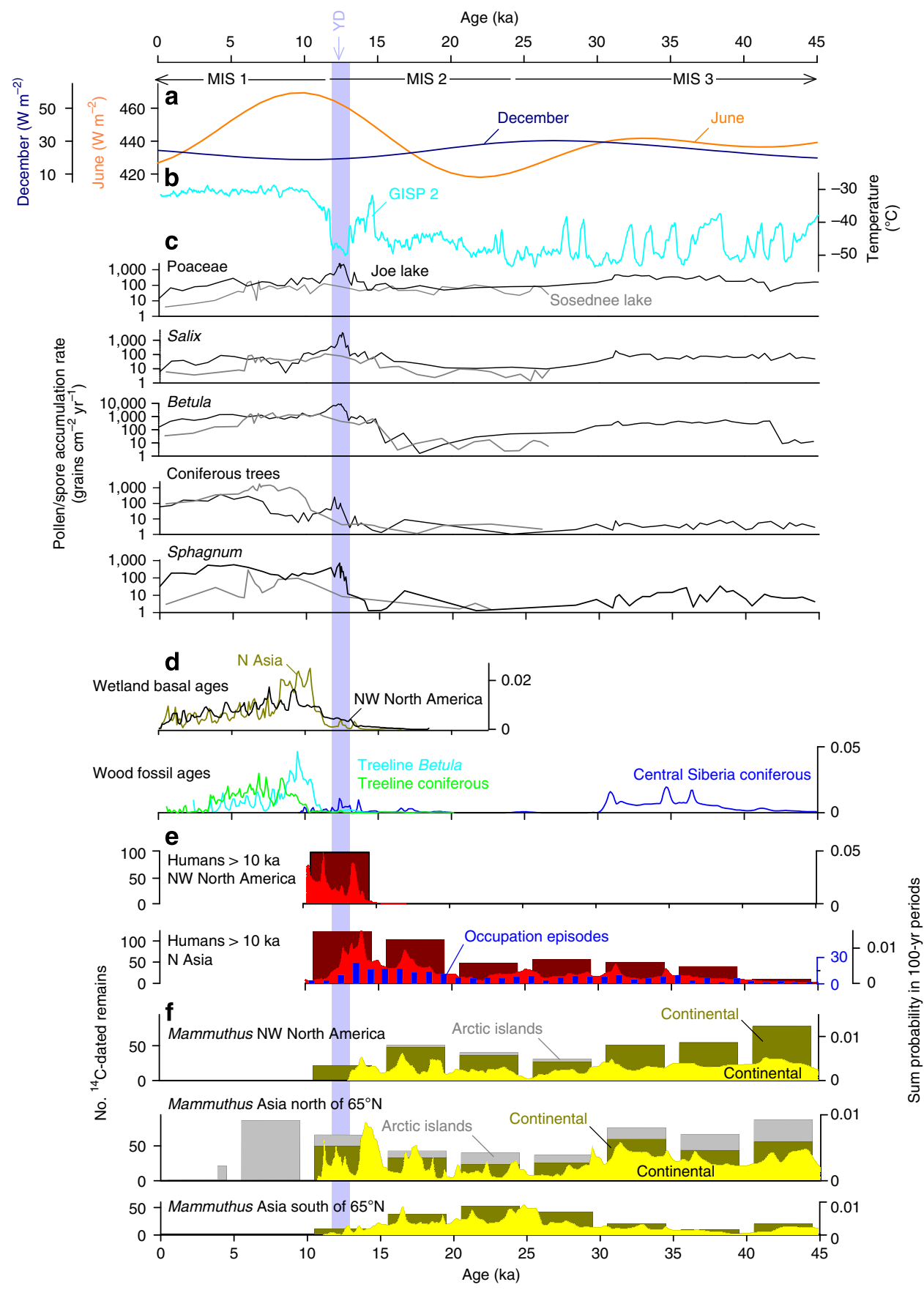

Figure 1 | Comparative time series of woolly mammoth abundance. Comparative time-series of orbital forcing, environmental factors, Paleolithic human sites and woolly mammoth abundance. (a). General boundaries of marine isotope stages (MIS 1,2,3) and June (orange) and December (dark blue) insolation variations at $60^{\circ} \mathrm{N}$. The timing of the YD is indicated. (b). Arctic surface temperatures as represented in Greenland Greenland GISP2 ice core (light blue). (c) Pollen/spore accumulation rates for Poaceae (grass),Salix (willow), Betula (birch), coniferous trees, and Sphagnum in northeastern Asia (Sosednee Lake, grey) and Alaska (Joe Lake, black). (d). Radiocarbon age probability plots for wetland/peatland initiation dates (olive green and black), and Betula (birch) (light blue) and treeline conifer macrofossils (lime green). Probability plot of radiocarbon ages from coniferous tree macrofossils from central Siberia is presented in blue. (e) Cumulative probabilities (sum probability in 100-yr periods) of northern Eurasian Paleolithic dates and occupation episodes (blue) per 1,000-year periods and cumulative probabilities of early Alaska-Yukon human occupation sites (red). The cumulative probabilities are overlain on simple histograms of the number of dates per 5,000-year interval (dark red). All human site data series are terminated at 10 ka. (f) Cumulative probabilities of northern Asian and northwestern North American woolly mammoth remains (yellow) overlain on simple histograms of the number of dates per 5,000-year interval (dark yellow). Histograms are divided by continental sites (yellow) and island sites (grey). Histograms are included as cumulative probability curves are prone to age-dependent bias as explained in Supplementary Information. For data sources and calculations, see Methods and Supplementary Data 1.

and shrubby vegetation including willows ${ }^{5,25-28}$ (Figs 1 and 4). Before the subsequent full development of large peatlands, dense birch cover and conifer forest (Figs 1-4), these conditions would have promoted woolly mammoth population growth in the north ${ }^{5}$. Populations in southern Siberia were, in contrast, declining relative to LGM levels, probably because of conifer forest and 


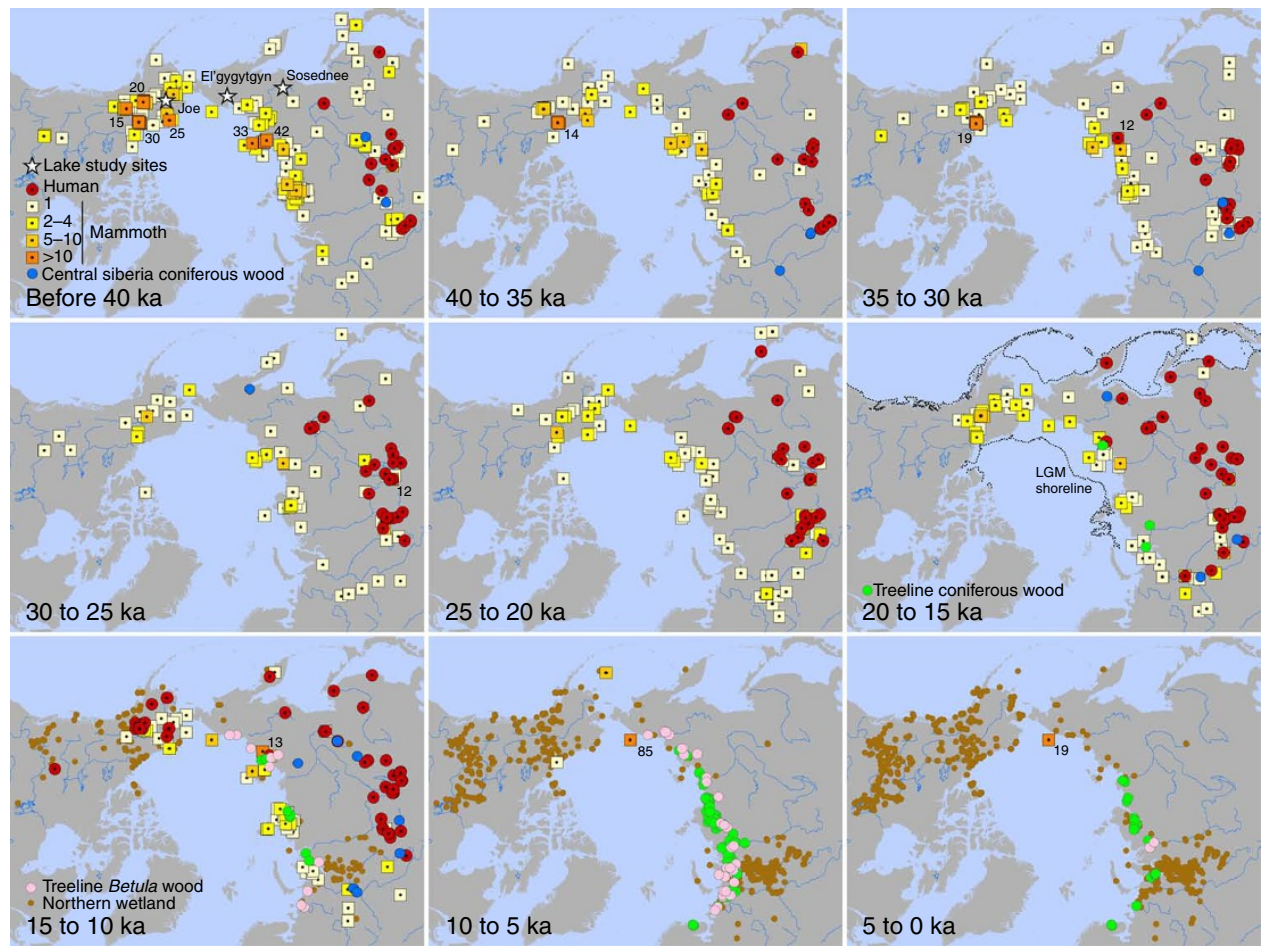

Figure 2 | Spatiotemporal patterns of woolly mammoth presence. Spatiotemporal patterns of woolly mammoth presence, environmental conditions and Paleolithic human sites. Time-slice maps of radiocarbon-dated mammoth remains (yellow and orange), Paleolithic human sites in northern Eurasia and early human occupation sites in Alaska and Yukon (red), wetland/peatland initiations (tan), and Betula (birch) (pink) and coniferous wood macrofossils from treeline in Eurasia (green) and central Siberia (blue). Stars indicate the location of Lake El'gygytgyn, Sosednee Lake and Joe Lake sites. Total number of dates from sites with >10 mammoth dates for any time-slice are noted. For data sources, see Methods and Supplementary Data 1.
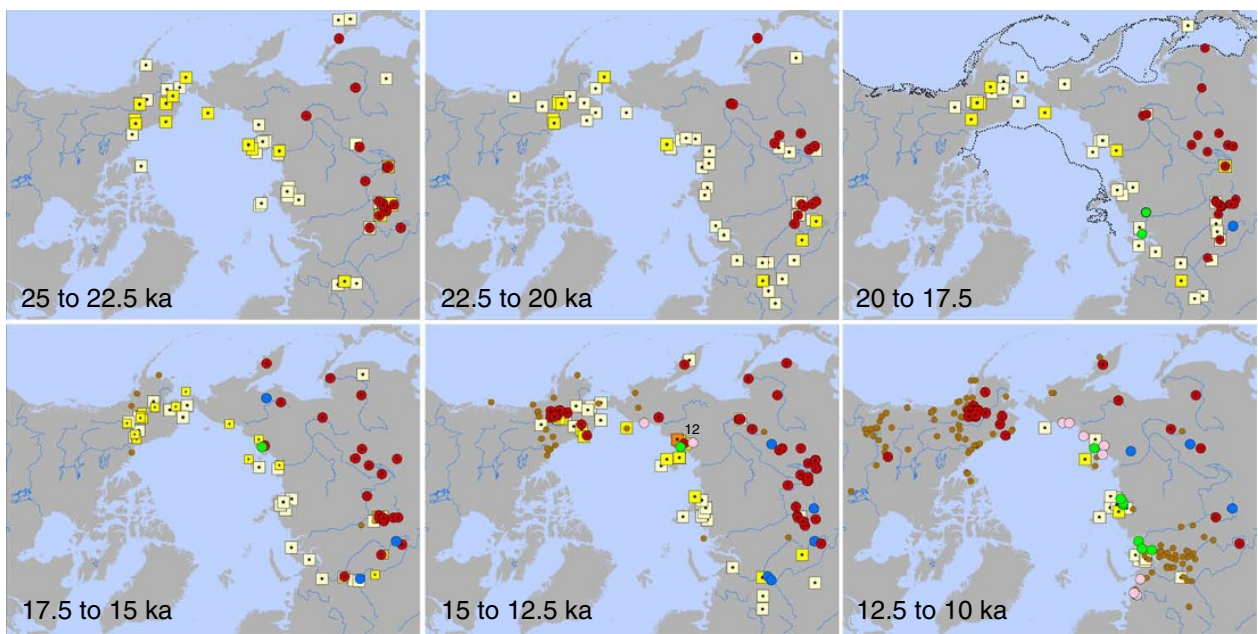

Figure 3 | Detailed spatiotemporal patterns of mammoth presence and environmental conditions. Detailed spatiotemporal patterns between $25 \mathrm{ka}$ and $10 \mathrm{ka}$ in $2.5 \mathrm{ka}$ time-slices. Time-slice maps and symbols follow Fig. 2-mammoth,yellow; Paleolithic sites, red; birch macrofossils, pink; interior Siberian conifer wood, blue, treeline conifer wood, green, peatlands/wetlands, tan.

peatland development and possibly greater human hunting pressures (Figs 1-4). The geographic distribution of the Asian population density was shifting back to a pattern of higher density in the north. However, unlike MIS 3, the more southerly populations seem to have disappeared almost entirely by $\sim 12.5 \mathrm{ka}$ (Figs 1-3).

Ultimate decline and Holocene extinction. A steep decline in woolly mammoths in northern North America occurred around the time of the YD at $\sim 12.9 \mathrm{ka}$ and in northern Asia, during the subsequent continued development of extensive birch cover, peatlands and conifer forest (Figs 1-4). Temperature reconstructions suggest a rapid cooling of $3.5^{\circ} \mathrm{C}$ to $8.9^{\circ} \mathrm{C}$ in portions of Alaska during the $\mathrm{YD}^{29}$. However, climatic and vegetation impacts were regionally variable ${ }^{28-30}$, and there is no clear vegetation change in the pollen records, presented here, that can be ascribed to the YD (Figs 1 and 4). Even in the face of vegetation resilience, a very rapid cooling could 

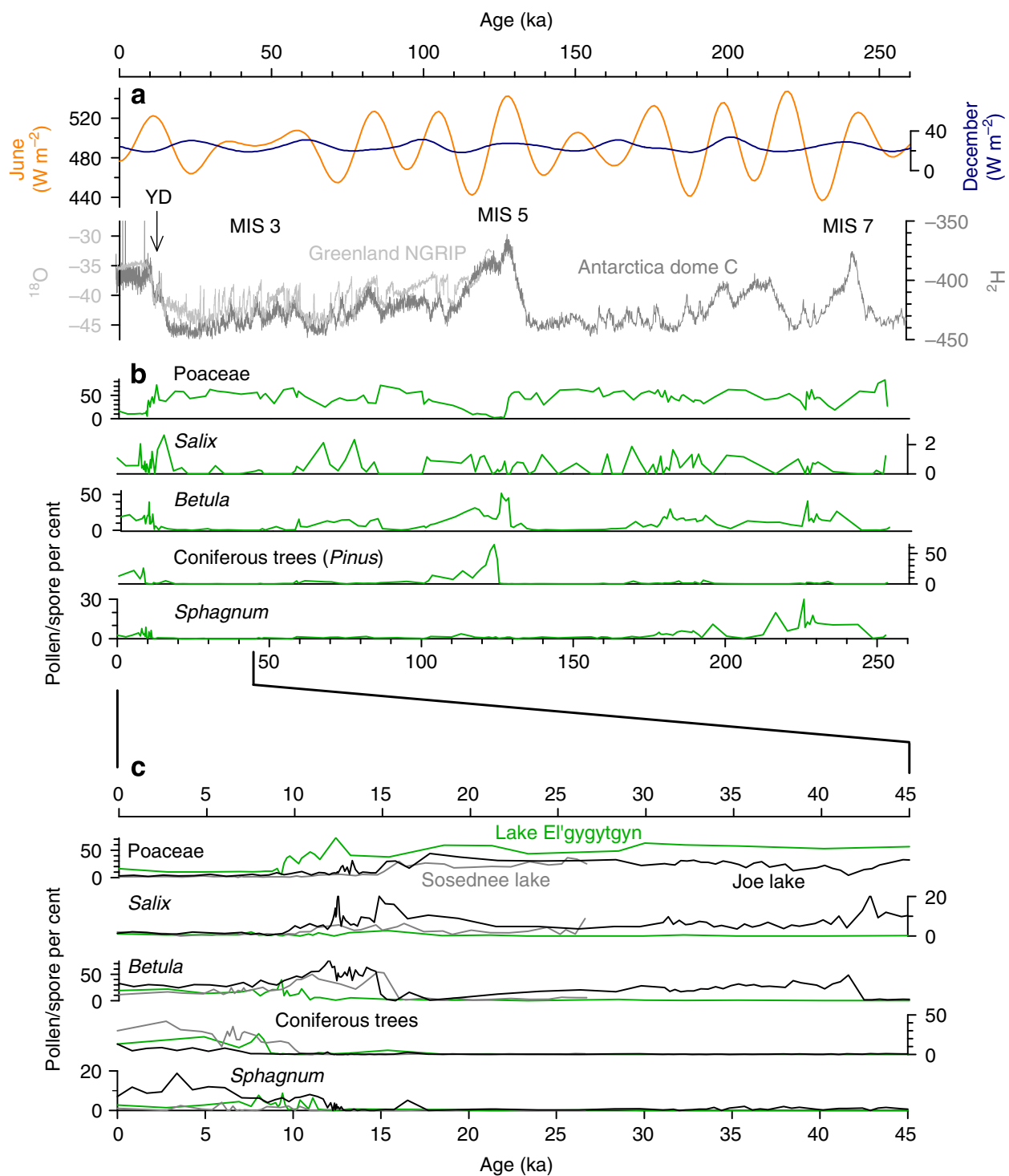

Figure 4 | Comparative time series of orbital forcing and pollen records from Beringia. Comparative time series of orbital forcing, ice-core climate evidence related to MIS 7-1, and pollen records from Beringia for the past $250 \mathrm{ka}$ and $45 \mathrm{ka}$. (a) June and December insolation variations at $60^{\circ} \mathrm{N}$, general timing of marine isotope stages (MIS 3, 5, 7) and the YD, oxygen-stable isotope record from the Greenland NGRIP ice core, deuterium stable isotope record from the Antarctica Dome C EPICA ice core, (b) Vegetation change in western Beringia over the last 250 ka as represented by pollen and spore percentages of Poaceae (grass), Salix (willow), Betula (birch), coniferous trees, and Sphagnum from Lake El'gygytgyn. (c) Vegetation change in eastern and western Beringia for the last $45 \mathrm{ka}$ as represented by pollen and spore percentages of Poaceae, Salix, Betula, coniferous trees, and Sphagnum from Lake El'gygytgyn and Sosednee Lake, Siberia and Joe Lake, Alaska. For data sources, see Methods.

have been more deleterious to large mammals that remain active year round. Stable isotope studies of woolly mammoth remains suggest that they did not migrate appreciable distances ${ }^{31}$, and confined latitudinal ranges would possibly have made them vulnerable in areas with pronounced cooling. In the absence of information on the specifics of mammoth physiology, the potential impacts of such an oscillation, however, remain uncertain. North American mammoth populations do seem to have declined coincidentally with the YD (Fig. 1), but such a decline is not as clear for Asia. Although it's potential impact on mammoths is still to be resolved, it is notable that a rapid climatic oscillation analogous to the YD does not appear to have occurred during the earlier MIS 6-MIS 5 glacial-interglacial transition ${ }^{32}$ through which $M$. primigenius survived.

Dated mammoth remains from after the YD come from northernmost Eurasia and Arctic islands (Continental Northern Asia $=5$, Arctic Islands=112). Small continental populations of woolly mammoth certainly were present after the $\mathrm{YD}^{6,33,34}$, but trajectory of these populations towards extinction was being driven by changing habitat and perhaps also through human hunting that had spread to North America (Fig. 3). Graminoid, willow and drier herbaceous cover decreased in concert with the establishment of deleterious birch shrubland/woodland throughout Beringia, development of extensive peatlands and wet tundra, and expansion of conifer forest including areas north of the modern treeline

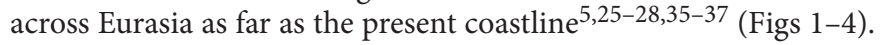
Pressure from hunting was also present, as contemporary Paleolithic sites are numerous in both Siberia and now in northwestern North America (Figs 1-3). Modelling studies show that given the environmental stresses at the time, even limited hunting by humans could have significantly contributed to woolly mammoth extinction ${ }^{7}$. Humans may have been even more widespread by this time than the radiocarbon database of Paleolithic sites 
captures. Although chronological control of older paleoenvironmental records presents uncertainties, ancestral mammoths had survived decreased grasslands, increased peatlands and extensive birch shrubland and conifer range expansion during the time of MIS 5 (ref. 35) (Fig. 4). However, the magnitude of the decrease in grassland and increase of pine during the Holocene and MIS 5 seems to be not typical of the earlier MIS 7 interglacial in northern Asia $^{35}$ (Fig. 4).

The geographic pattern of Beringian mammoth extinction, seems to be one of the final populations existing on the northern periphery of a once more extensive range ${ }^{37}$ (Figs 2 and 3). This pattern is consistent with the open vegetation available on the fringes of the continents and perhaps less intense human hunting there. As sea-level rose during the Late Glacial and Early Holocene, some of these northern mammoth populations were isolated on what became Wrangel Island and the Pribilof Islands ${ }^{10-12}$. The last surviving mammoths on Wrangel Island may have been driven to extinction by stochastic factors related to their being a small and isolated population, hunting by newly arrived humans or disease ${ }^{38}$. They may also have been affected by cooling during the Neoglacial, which is evident in treeline retreat across northern Eurasia at $\sim 4 \mathrm{ka}$ (ref. 36). Unfortunately, it seems that no mammoths were left on continental Asia to take advantage of opening of vegetation as treeline retreated after $4 \mathrm{ka}$.

\section{Discussion}

Not one, but several factors would have made the present interglacial particularly challenging for woolly mammoths in Beringia: the preceding declines in northern populations during the LGM; the rapid and relatively early development of unpalatable birch shurbland; wet tundra and extensive peatlands/wetlands followed by the expansion of conifer forest and woodland to the continental margins in Eurasia; the presence of modern humans not only in Siberia, but now also in North America; and the sudden, but regionally differing, impacts of the YD oscillation. The relative importance of these specific forces may never be wholly resolvable, and was likely regionally variable, but combined, they provided the lethal intersection $^{1}$ of factors to drive the woolly mammoths to extinction in continental Beringia with relictual populations hanging on for several millennia on isolated Arctic islands. That final extinction of the island populations signalled the conclusion of the long sunset of the woolly mammoths in Beringia after over 20,000 years of multiple environmental challenges related to changes in climate, habitat and human predation.

\footnotetext{
Methods

Radiocarbon dating. Radiocarbon date sources and details of all dated mammoth samples are provided in Supplementary Data 1. Radiocarbon dates from remains of $M$. primigenius $(n=1323)$, Paleolithic archaeological sites $(n=576)$, basal ages of wetland peat deposits within $750 \mathrm{~km}$ of woolly mammoth remains $(n=658)$, wood macrofossils from treeline and central regions of Siberia $(n=447)$ and Beringia lake sediments $(n=19)$ were calibrated and reported as ka (thousands of years before AD 1950), using the IntCal09 dataset ${ }^{39}$ in CALIB. Dates without specific geo-references, laboratory numbers were excluded. We consider radiocarbon dates $\geq 42,000{ }^{14} \mathrm{C}$ yr BP as potentially $>45 \mathrm{ka}$ owing to uncertainties in processing, measurement and calibration of old samples ${ }^{19,39,40}$. We believe that given the size and geographic extent of the mammoth data set that large changes in the number of dated samples reflects general trends in mammoth abundance ${ }^{2}$. We do not, however, affix any interpretation to finer features such as intermillennial variations in sample numbers.

Analysis of the calendar age-range of the $2-\sigma$ probability distribution of the uncertainty of the age of radiocarbon-dated mammoth remains (measurement and calibration uncertainty) shows increasing magnitude with age. This is particularly acute for time periods earlier than $15 \mathrm{ka}$ (Supplementary Fig. S1). Simple sums of the number of age-probability distributions that intersect a given time period are thus age-biased and would over estimate abundances for time periods beyond $15 \mathrm{ka}$. Therefore, mammoth dates are presented as both simple histograms of the number of mammoth dates (medians of calibrated probability distributions) per 5,000 -year interval and the cumulative sum of the total calibrated probability distributions (cumulative probability) in 100 -yr periods.
}

Care must be taken in the use of large radiocarbon data sets, and debate exists over the best approaches ${ }^{41-44}$. We have avoided known apatite bone dates for mammoths (Supplementary Data 1), attempted to select archaeological dates with clear context and further mitigate problems in the dating of Asian sites by using occupation-age estimates (see below) that are often based on multiple dates, and we have only incorporated dates from laboratories that we believe participated in either international or internal Soviet/Russian multi-lab intercomparisons. Although issues may still persist with individual dates, we believe the total numbers, incorporated in the analysis, portray overall general records of abundance and geographic patterns with acceptable fidelity.

Archaeological dates and Eurasian occupation episodes. The dates for Paleolithic sites are from a number of sources $s^{5,45-47}$, and those from Eurasian Paleolithic sites were used to calculate occupation-episode estimates for 1,000-year time-slices to remove any bias introduced by sites that have many dates for a single occupation period owing to the employed sampling and dating methods ${ }^{45-47}$. The occupation episode totals for each time-slice represent the number of geographically discrete sites that have dates indicating human presence during that time period.

Other paleoenvironmental data sets and chronologies. Online data for June and December insolation variations at $60^{\circ} \mathrm{N}$ (ref. 48), temperature and oxygen stable isotope records from the Greenland GISP2 and NGRIP ice cores ${ }^{49,50}$, deuterium stable isotope record from the Antarctica EPICA Dome C ice core ${ }^{51}$ and the pollen and spore data for the Joe Lake and Sosednee Lakes cores ${ }^{52,53}$ were obtained from the NOAA National Climate Data Center site (www.ncdc.noaa.gov/paleo). Additional data for Sosednee Lake were provided by Dr Pat Anderson. Chronologies were constructed by fitting a cubic spline to the sediment age-depth relationship based on calibrated ${ }^{39}$ radiocarbon dates. Pollen and spore concentrations for Lake El'gygytgyn were received in digital format courtesy of Drs Anatoly Lozhkin and Pat Andersen and are from 2005. As presented, they may differ slightly in terms of pollen sum used to calculate percentages, details of counts and subsamples represented in previously published form ${ }^{35}$. There has been previous discussion regarding the chronology for Lake El'gygytgyn ${ }^{35,54-55}$, and we use an updated chronology incorporating orbital tuning provided by Drs Norbert Nowaczyk and Julie Brigham-Grette. Peat/wetland initiation and wood macrofossil dates are from several sources $19,36,56,57$.

Bayesian skyline plots. BSPs (Supplementary Fig. S1) were reconstructed for a data set of 103 mammoth mitochondrial control region sequences, comprising all currently available sequence data ${ }^{20,58}$. Analyses were performed in BEASTS 59,60 using the $\mathrm{HKY}+\mathrm{G}$ model of nucleotide substitution and calibrated radiocarbon dates to constrain the molecular clock. The significance of the downward trend in diversity was investigated using Bayes Factors ${ }^{60}$ to compare two different coalescent priors: the flexible BSP ${ }^{58}$ and a constant-size coalescent prior. The BSP is a piecewise-constant coalescent model, in that it allows several different constant population sizes to have existed throughout the sampled evolutionary history (in this case ten different population sizes), and then averages these estimates across the a posteriori sampled trees. For each analysis, two Monte Carlo Markov chains were run for $30 \mathrm{M}$ iterations, with samples drawn from the posterior every 3,000 iterations. After checking for appropriate mixing and convergence, the first $10 \%$ of samples from the posterior were discarded and the remainder combined. BSPs and Bayes Factorss were estimated using Tracer v $1.5^{61}$.

\section{References}

1. Barnosky, A. D., Koch, P. L., Feranec, R. S., Wing, S. L. \& Shabel, A. B. Assessing the causes of late Pleistocene extinctions on the continents. Science 306, 70-75 (2004).

2. Nikolskiy, P. A., Sulerzhitsky, L. D. \& Pitulko, V. V. Last straw versus Blitzkrieg overkill: Climate-driven changes in the Arctic Siberian mammoth population and the Late Pleistocene extinction problem. Quaternary Sci. Rev. 30, 2309-2328 (2011).

3. Stuart, A. J., Sulerzhitsky, L. D., Orlova, L. A., Kuzmin, Y. V. \& Lister, A. M. The latest woolly mammoths (Mammuthus primigenius Blumenbach) in Europe and Asia: a review of the current evidence. Quaternary Sci. Rev. 21, 1559-1569 (2002)

4. Stuart, A. J., Kosintsev, P. A., Higham, T. F. G. \& Lister, A. M. Pleistocene to Holocene extinction dynamics in giant deer and woolly mammoth. Nature 431, 684-689 (2004)

5. Guthrie, R. D. New carbon dates link climatic change with human colonization and Pleistocene extinctions. Nature 441, 207-209 (2006).

6. Kuzmin, Y. V. Extinction of the woolly mammoth (Mammuthus primigenius) and woolly rhinoceros (Coelodonta antiquitatis) in Eurasia: review of chronological and environmental issues. Boreas 39, 247-261 (2010).

7. Nogués-Bravo, D., Rodríguez, J., Hortal, J., Batra, P. \& Araújo, M. B. Climate change, humans, and the extinction of the woolly mammoth. PLoS Biol. 6, e79 (2008).

8. Lorenzen, E. D. et al. Species-specific responses of Late Quaternary megafauna to climate and humans. Nature 479, 359-365 (2011)

9. Guthrie, R. D. Frozen Fauna of the Woolly Mammoth Steppe (Univ. Chicago Press, Chicago, 1990). 
10. Vartanyan, S. L., Arslanov, K. A., Karhu, J. A., Possnert, G. \& Sulerzhitsky, L. D. Collection of radiocarbon dates on the woolly mammoths (Mammuthus primigenius) and other genera of Wrangel Island, northeast Siberia, Russia. Quaternary Research 70, 51-59 (2008).

11. Guthrie, R. D. Radiocarbon evidence of mid-Holocene woolly mammoths stranded on an Alaskan Bering Sea island. Nature 429, 746-749 (2004).

12. Kuzmin, Y. V. \& Orlova, L. A. Radiocarbon chronology and environment of woolly mammoth (Mammuthus primigenius Blum.) in northern Asia: results and perspectives. Earth-Sci. Rev. 68, 133-169 (2004).

13. Surovell, T. A., Waguespack, N. M. \& Brantingham, P. J. Global archaeological evidence for Proboscidean overkill. Proc. Natl Acad. Sci. USA 102, 6231-6236 (2005).

14. Firestone, R. B. et al. Evidence for an extraterrestrial impact 12,900 years ago that contributed to the megafaunal extinctions and the Younger Dryas cooling. Proc. Natl Acad. Sci. USA 104, 16016-16021 (2007).

15. Gilbert, M. T. P. et al. Intraspecific phylogenetic analysis of Siberian woolly mammoths using complete mitochondrial genomes. Proc. Natl Acad. Sci. USA 105, 8327-8332 (2008)

16. Elias, S. A. Mutual climatic range reconstructions of seasonal temperatures based on Late Pleistocene fossil beetle assemblages in eastern Beringia. Quaternary Sci. Rev. 20, 77-91 (2001).

17. Anderson, P. M. \& Lozhkin, A. V. The Stage 3 interstadial complex (Karginskii/ middle Wisconsinan interval) of Beringia: variations in paleoenvironments and implications for paleoclimatic interpretations. Quaternary Sci. Rev. 20, 93-125 (2001).

18. van Geel, B. et al. The ecological implications of a Yakutian woolly mammoth's last meal. Quaternary Res. 69, 361-376 (2008).

19. MacDonald, G. M. et al. Rapid early development of circumarctic peatlands and atmospheric $\mathrm{CH}_{4}$ and $\mathrm{CO}_{2}$ variations. Science 314, 285-288 (2006).

20. Debruyne, R. et al. Out of America: ancient DNA evidence for a New World origin of Late Quaternary woolly mammoths. Curr. Biol. 18, 1320-1326 (2008).

21. Barnes, I. et al. Genetic structure and extinction of the woolly mammoth, Mammuthus primigenius. Curr. Biol. 17, 1072-1075 (2007).

22. Shapiro, B. et al. Rise and fall of the Beringian steppe bison. Science 306, 1561-1565 (2004)

23. Kim, S- J., Flato, G. M. \& Boer, G. J. A coupled climate model simulation of the Last Glacial Maximum, Part 2: approach to equilibrium. Clim. Dynam. 20, 635-661 (2003).

24. Zazula, G. D. et al. Ice-age steppe vegetation in east Beringia. Nature 423, 603 (2003).

25. Cwynar, L. \& Ritchie, J. C. Arctic steppe-tundra: a Yukon perspective. Science 208, 1375-1377 (1980)

26. Anderson, P. M., Reanier, R. E. \& Brublaker, L. B. A 14,000-year pollen record from Sithylemenkat Lake, north-central Alaska. Quaternary Res. 33, 400-404 (1990)

27. Kokorowski, H. D. et al. Late glacial and early Holocene climatic changes based on a multiproxy lacustrine sediment record from northeast Siberia. Arct. Antarct. Alp. Res. 40, 497-505 (2008).

28. Kureka, J., Cwynar, L. C. \& Vermaire, J. C. A late Quaternary paleotemperature record from Hanging Lake, northern Yukon Territory, eastern Beringia. Quaternary Res. 72, 246-257 (2009).

29. Hu, F. S. \& Shemesh, A. A biogenic-silica $\delta^{18} \mathrm{O}$ record of climatic change during the last glacial-interglacial transition in southwestern Alaska. Quaternary Res. 59, 379-385 (2003).

30. Kokorowski, H. D., Anderson, P. M., Mock, C. J. \& Lozhkin, A. V. A re-evaluation and spatial analysis of evidence for a Younger Dryas climatic reversal in Beringia. Quaternary Sci. Rev. 27, 1710-1722 (2008).

31. Fox, D. L. et al. Paleoclimatic implications of oxygen isotopic variation in late Pleistocene and Holocene tusks of Mammuthus primigenius from northern Eurasia. Quaternary Int. 169-170, 154-165 (2007).

32. Carlson, A. E. Why there was not a Younger Dryas-like event during the Penultimate Deglaciation. Quaternary Sci. Rev. 27, 882-887 (2008).

33. Orlova, L. A. et al. Lugovskoe, West Siberia: a possible extra-Arctic woolly mammoth refugium at the end of the Late Glacial. Radiocarbon 46, 363-368 (2004)

34. Haile, J. et al. Ancient DNA reveals late survival of woolly mammoth and horse in interior Alaska. Proc. Natl Acad. Sci. USA 106, 22352-22357 (2009).

35. Lozhkin, A. V., Anderson, P. M., Matrosova, T. V. \& Minyuk, P. S. The pollen record from El'gygytgyn Lake: implications for vegetation and climate histories of northern Chukotka since the late middle Pleistocene. J Paleolimnol. 37, 135-153 (2007).

36. MacDonald, G. M., Kremenetski, K. V. \& Beilman, D. W. Climate change and the northern Russian treeline zone. Phil. Trans. R. Soc. B 363, 2285-2299 (2008).

37. Sher, A. V. in Past and Future Rapid Environmental Changes: the Spatial and Evolutionary Responses of Terrestrial Biota, 319-339. NATO ASI Series 1: Global Environmental Change (eds Huntley, B. et al.) Vol. 47 (Springer, 1997).
38. Nyström, V. et al. Temporal genetic change in the last remaining population of woolly mammoth. Proc. R. Soc. B 277, 2331-2337 (2010).

39. Reimer, P. J. et al. IntCal09 and Marine09 radiocarbon calibration curves, 0-50,000 years cal BP. Radiocarbon 51, 1111-1150 (2009).

40. Stafford, T. W. et al. Accelerator radiocarbon dating at the molecular level. J. Archaeol. Sci. 18, 35-72 (1991).

41. Pettitt, P. B., Davies, S. W. G., Gamble, C. S. \& Richards, M. B. Palaeolithic radiocarbon chronology: quantifying our confidence beyond two half-lives. J. Archaeol. Sci. 30, 1685-93 (2003).

42. Graf, K. E. 'The Good, the Bad, and the Ugly': evaluating the radiocarbon chronology of the middle and late Upper Palaeolithic in the Enisei River valley, south-central Siberia. J. Archaeol. Sci. 36, 694-707 (2009).

43. Kuzmin, Y. V. Comments on Graf, Journal of Archaeological Science 36, 2009 "The Good, the Bad, and the Ugly": evaluating the radiocarbon chronology of the middle and late Upper Palaeolithic in the Enisei River valley, south-central Siberia. J. Archaeol. Sci. 36, 2730-2733 (2009).

44. Barnosky, A. D. \& Lindsey, E. L. Timing of Quaternary megafaunal extinction in South America in relation to human arrival and climate change. Quaternary Internat. 217, 10-29 (2010).

45. Vasil'ev, S. A., Kuzmin, Y. V., Orlova, L. A. \& Dementiev, V. N. Radiocarbonbased chronology of the Palaeolithic in Siberia and its relevance to the peopling of the New World. Radiocarbon 44, 503-530 (2002).

46. Kuzmin, Y. V. \& Keates, S. G. Dates are not just data: Palaeolithic settlement patterns in Siberia derived from radiocarbon records. Am. Antiquity 70, 773-789 (2005)

47. Fiedel, S. J. \& Kuzmin, Y. V. Radiocarbon date frequency as an index of intensity of Palaeolithic occupation of Siberia: did humans react predictably to climate oscillations? Radiocarbon 49, 741-756 (2007)

48. Berger, A. \& Loutre, M. F. Insolation values for the climate of the last 10 million years. Quaternary Sci. Rev. 10, 297-317 (1991).

49. Alley, R. B. The Younger Dryas cold interval as viewed from central Greenland. Quaternary Sci. Rev. 19, 213-226 (2000)

50. North Greenland Ice Core Project Members. High-resolution record of Northern Hemisphere climate extending into the last interglacial period. Nature 431, 147-151 (2004).

51. Jouzel, J. et al. Orbital and millennial Antarctic climate variability over the past 800,000 years. Science 317, 793-797 (2007).

52. Anderson, P. M. Late Quaternary pollen records from the Kobuk and Noatuk River drainages, northwestern Alaska. Quaternary Res. 29, 263-276 (1998).

53. Lozhkin, A. V. et al. Late Quaternary pollen records from southwestern Beringia. Quaternary Res. 39, 314-324 (1993).

54. Nowaczyk, N. et al. Magnetostratigraphic results from impact crater Lake El'gygytgyn, northeastern Siberia: a $300 \mathrm{kyr}$ long high-resolution terrestrial palaeoclimatic record from the Arctic. AGU EOS Trans. 150, 109-129 (2002).

55. Nowaczyk, N. R. \& Melles, M. A. Revised age model for core PG1351 from Lake El'gygytgyn, Chukotka, based on magnetic susceptibility variations correlated to northern hemisphere insolation variations. J. Paleoliminol. 37, 89-104 (2007).

56. MacDonald, G. M. et al. Holocene treeline history and climate change across northern Eurasia. Quat. Res. 53, 302-311 (2000).

57. Binney, H. A. et al. The distribution of late-Quaternary woody taxa in northern Eurasia: evidence from a new macrofossil database. Quat. Sci. Rev. 28, 2445-2464 (2009).

58. Drummond, A. J., Rambaut, A., Shapiro, B. \& Pybus, O. G. Bayesian coalescent inference of past population dynamics from molecular sequences. Mol. Biol. Evol. 22, 1185-1192 (2005)

59. Drummond, A. J. \& Rambaut, A. BEAST: Bayesian evolutionary analysis by sampling trees. BMC Evol. Biol. 7, 214 (2007).

60. Suchard, M. A., Weiss, R. E. \& Sinsheimer, J. S. Bayesian selection of continuous-time Markov chain evolutionary models. Mol. Biol. Evol. 18, 1001-1013 (2001).

61. Rambaut, A. Tracer v1.5 Available from http://tree.bio.ed.ac.uk/software/tracer/ (2007).

\section{Acknowledgements}

We thank Drs Dale Guthrie and Steven Stanley who examined earlier drafts of the manuscript. Their questions, comments and suggestions greatly improved the paper. We thank Drs Dale Guthrie, Pat Anderson, Julie Brigham-Grette, Anatoly Lozhkin and Norbert Nowaczyk for providing access to published and unpublished digital data. This research was directly supported by NSF Office of Polar Programs Award 0352604 and incorporated additional data from NSF Awards 0628598 and 9818496.

\section{Author contributions}

G.M. was the co-principal investigator with responsibility for the the paleoecology section of the project and conceived the analysis presented, assembled team, worked on database acquisition, analysis and interpretation, and wrote initial draft and revisions. 
D.B. worked on analysis and interpretation of the spatial and temporal data, radiocarbon age calibration, uncertainty analysis, summed probabilities, GIS mapping and graphical representations. Y.K. worked on Russian Paleolithic database acquisition and mammoth database acquisition, analysis and detailed synthesis and interpretation of the results. L.O. worked on Russian mammoth radiocarbon dating and database acquisition and analysis. K.K. worked on Russian and North American database acquisition for mammoths and paleoenvironental proxies, data vetting and geo-references and data acquisition and calculations related to palynological data. B.S. acquired mammoth genetic data, provided the BSP analysis, interpretation and discussion. R.W. was principal investigator on the overall research program and worked on analysis of and discussion of the genetics data and BSP results from this and earlier papers. B.V.V. was a co prinicipal investigator on the project and worked on comparison of paleontological data with genetics data and robustness of paleontological data, in terms of representing mammoth populations. All co-authors contributed to drafting of initial manuscript and revision of manuscripts and responding to review comments in their specific areas of expertise.

\section{Additional information}

Supplementary Information accompanies this paper at http://www.nature.com/ naturecommunications

Competing financial interests: The authors declare no competing financial interests.

Reprints and permission information is available online at http://npg.nature.com/ reprintsandpermissions/

How to cite this article: MacDonald, G.M. et al. Pattern of extinction of the woolly mammoth in Beringia. Nat. Commun. 3:893 doi: 10.1038/ncomms1881 (2012).

License: This work is licensed under a Creative Commons Attribution-NonCommercialShare Alike 3.0 Unported License. To view a copy of this license, visit http:// creativecommons.org/licenses/by-nc-sa/3.0/ 